\title{
Pengaruh Metode Ekstraksi terhadap Kadar Fenol dan Flavonoid Total, Aktivitas Antioksidan serta Antilipase Daun Jati Belanda (Guazuma ulmifolia)
}

(Effect of extraction methods on total phenol and flavonoid contents, antioxidant and antilipase activities of West Indian elm leaves (Guazuma ulmifolia))

\author{
Nuri*, Endah Puspitasari, Mochammad Amrun Hidayat, Indah Yulia Ningsih, \\ Bawon Triatmoko, \& Dewi Dianasari \\ Fakultas Farmasi Universitas Jember, Jl. Kalimantan I No. 2 Sumbersari, Jember, Jawa Timur
}

\begin{abstract}
The leaf of Guazuma ulmifolia has been used traditionally for antiobesity. The activity of antiobesity was affected by the content of bioactive compounds. Extraction is the primary step to obtain bioactive compounds from plant material. The method and solvent used for extraction are crucial factors to produce extracts that have a high amount of active compounds. This study aims to determine the total phenolic and total flavonoids content from ethanolic extracts, water extract, and infusions of $G$. ulmifolia leaf and to evaluate the antioxidant and antilipase activity. Folin-Ciocalteu method was used to determine the phenolic content, while flavonoid content determination was done using aluminium chloride colorimetric assay. The antioxidant activity was done using 2,2-diphenyl-1-picrylhydrazyl (DPPH) assay, and the antilipase activity was quantified using p-nitrophenol release from p-nitrophenyl butyrate ( $\mathrm{p}-\mathrm{NPB}$ ) substrate-colorimetric assay. The result of G. ulmifolia leaf extraction showed that the highest yield was obtained from water extraction (10.50\%). Whereas, the ethanolic extract was showed the highest total phenolic content (67.761 $\pm 1.811 \mathrm{mg} \mathrm{GAE} / \mathrm{g}$ extract) and the highest total flavonoid content (124.643 $\pm 1.033 \mathrm{mg}$ QE/g extract). The same extract also exhibited the highest antioxidant activity $\left(I C_{50}=6.544 \pm 0.271 \mu \mathrm{g} / \mathrm{mL}\right)$ and antilipase activity $\left(I C_{50}=307.280 \pm 21.430 \mu \mathrm{g} / \mathrm{mL}\right)$.
\end{abstract} Keywords: west indian elm; Guazuma ulmifolia; extraction methods; antioxidant; antilipase.

ABSTRAK: Daun Guazuma ulmifolia telah digunakan secara tradisional untuk antiobesitas. Aktivitas antiobesitas dipengaruhi oleh kandungan senyawa bioaktif. Ekstraksi adalah langkah utama untuk mendapatkan senyawa bioaktif. Metode dan pelarut ekstraksi merupakan faktor penting untuk menghasilkan ekstrak dengan jumlah kandungan senyawa aktif yang tinggi. Penelitian ini bertujuan untuk menentukan kadar fenol dan flavonoid total dari ekstrak etanol, rebusan, dan infusa daun G. ulmifolia serta untuk menentukan aktivitas antioksidan serta antilipase. Metode Folin-Ciocalteu digunakan untuk menentukan kadar fenol total, sedangkan penentuan kadar flavonoid total dilakukan menggunakan uji kolorimetri aluminium klorida. Aktivitas antioksidan ditentukan dengan metode 2,2-difenil-1-pikrillhidrazil (DPPH), dan aktivitas antilipase dikuantifikasi secara kolorimetri berdasarkan pelepasan $p$-nitrofenol dari substrat $p$-nitrofenil butirat (p-NPB). Hasil penelitian menunjukkan bahwa rebusan memiliki rendemen tertinggi (10,50\%). Sebaliknya, ekstrak etanol menunjukkan total kandungan fenolik tertinggi $(67,761 \pm 1,811 \mathrm{mg}$ GAE/g ekstrak) dan total kandungan flavonoid tertinggi (124,643 $\pm 1,033 \mathrm{mg}$ QE/g ekstrak). Ekstrak yang sama juga menunjukkan aktivitas antioksidan dan aktivitas antilipase tertinggi ( $\left(\mathrm{C}_{50}\right.$ berturut-turut 6,544 $\pm 0,271 \mu \mathrm{g} / \mathrm{mL}$ dan 307,280 $\pm 21,430 \mu \mathrm{g} / \mathrm{mL}$ ).

Kata kunci: jati belanda; Guazuma ulmifolia; metode ekstraksi; antioksidan; antilipase.

\section{Pendahuluan}

Tumbuhan Guazuma ulmifolia telah digunakan secara tradisional untuk antiobesitas dan antihiperlipidemia oleh masyarakat di Indonesia dengan cara merebus beberapa daun dengan air sampai volumenya tinggal $3 / 4$ volume asal [1]. Beberapa hasil penelitian terdahulu melaporkan bahwa ekstrak air daun G. ulmifolia memiliki efek antihiperlipidemia [2]. Demikian juga kombinasi ekstrak air daun G. ulmifolia dan ekstrak etanol rimpang C. xanthorrbiza [3]. Penelitian lain menunjukkan bahwa ekstrak etanol daun G. ulmifolia yang diberikan kepada tikus selama 14 hari dapat mengurangi berat badan secara bermakna dibandingkan dengan kontrol [4]. Salah satu mekanisme aktivitas senyawa antiobesitas adalah dengan menghambat lipase pankreas [5]. Kandungan fitokimia yang dapat menghambat aktivitas lipase pankreas antara lain polifenol dan flavonoid. Ada korelasi positif yang bermakna

*Corresponding Author: Nuri Fakultas Farmasi Universitas Jember, Krajan Timur, Sumbersari, Kec. Sumbersari, Kabupaten Jember, Jawa Timur, 68121| Email: nuri.farmasi@gmail.com

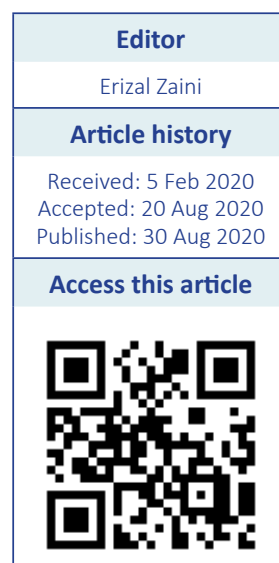


antara penghambatan lipase pankreas dengan kadar fenol dan flavonoid dari 28 tanaman obat [6].

Ekstrak daun G. ulmifolia memiliki beberapa kandungan fitokimia, termasuk polifenol dan flavonoid [7] antara lain; asam kafeat, asam klorogenat, kuersetin, kuersitrin, katekin, luteolin, rutin, dan tilirosid. Struktur kimia senyawa-senyawa tersebut ditunjukkan Gambar 1 [8,9]. Hasil penelitian efek hambatan lipase ekstrak-ekstrak Z. cassumunar, G. ulmifolia, dan M. paniculata menunjukkan bahwa ketiganya mampu menghambat lipase. Demikian juga campuran ketiga ekstrak tersebut menunjukkan hal yang sama, tetapi efek hambatannya lebih kecil dibandingkan ekstrak tunggal. Hasil penelitian tersebut juga menunjukkan bahwa ekstrak $G$. ulmifolia memiliki kandungan flavonoid dan tanin lebih tinggi dibandingkan senyawa lainnya serta dibandingkan ekstrak tanaman lainnya [10]. Keberadaan senyawa-senyawa ini diyakini berperan dalam mencegah dan mengobati obesitas melalui penghambatan enzim lipase dan mencegah stres oksidatif [11-13].

Ekstraksi merupakan langkah utama untuk memperoleh senyawa bioaktif dari simplisia tanaman.
Kadar senyawa bioaktif dalam ekstrak tergantung pada beberapa faktor. Metode dan pelarut yang digunakan untuk ekstraksi adalah faktor penting untuk menghasilkan ekstrak yang memiliki kadar senyawa bioaktif yang tinggi [14]. Seperti disebutkan di atas, secara tradisional proses ekstraksi G. ulmifolia dilakukan dengan merebus daun dengan air. Hasil ekstraksi ini umumnya disebut "jamu". Di sisi lain, menurut Farmakope Indonesia, daun diekstraksi dengan menggunakan air pada $90{ }^{\circ} \mathrm{C}$ selama 15 menit untuk mendapatkan infusa. Kedua cara penyiapan herbal ini (jamu dan infusa) dimaksudkan untuk segera digunakan. Namun demikian untuk industri obat tradisional, yang biasanya membutuhkan ekstrak dalam bentuk kering, metode ini kurang efisien karena tingginya biaya penguapan air tanpa merusak senyawa bioaktif. Mereka menggunakan pelarut organik untuk mengekstrak senyawa bioaktif dari bahan tanaman untuk memudahkan proses pengeringan. Oleh karena itu tujuan dari penelitian adalah untuk mengevaluasi pengaruh cara penyiapan daun G. ulmifolia, yaitu rebusan, infusa, dan ekstrak etanol, terhadap kadar fenol dan flavonoid total serta terhadap aktivitas antioksidan dan aktivitas antilipase.

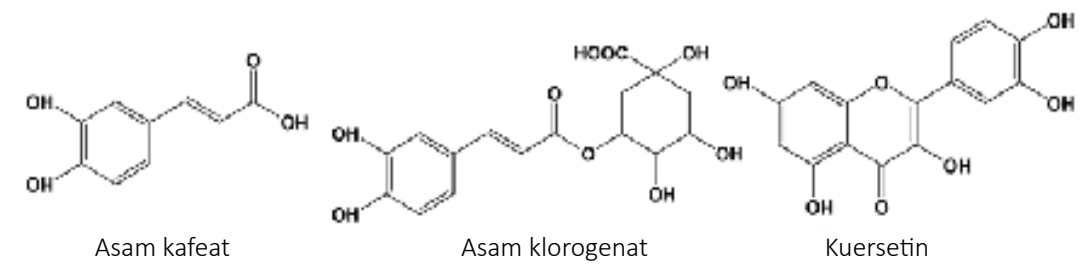<smiles>CCOC(=O)C1Oc2cc(O)cc(O)c2C(=O)C1O</smiles><smiles>CC1OC(OCC2OC(OC3=C(C4=CCC(O)C(O)C4)Oc4cc(O)cc(O)c4C3C(=O)O)C(O)C(O)C2O)C(O)C(O)C1O</smiles>

Kuersetin<smiles>COC1OC(C)C(O)C(O)C1O</smiles><smiles>CC1OC(Oc2c(-c3ccc(O)c(O)c3)oc3cc(O)cc(O)c3c2=O)C(O)C(O)C1O</smiles>

Gambar 1. Kandungan polifenol dan flavonoid daun G. Ulmifolia 


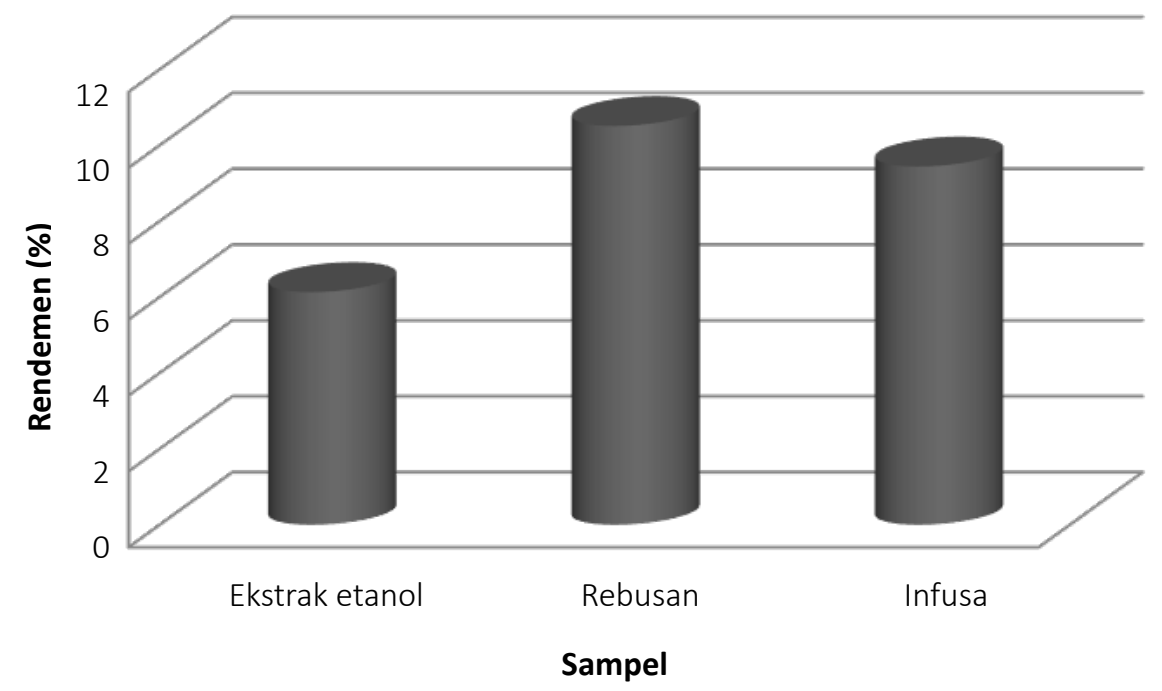

Gambar 2. Hasil ekstraksi daun G. ulmifolia

\section{Metode Penelitian}

\section{Bahan}

Bahan yang digunakan adalah porcine pancreatic lipase (PPL) (Sigma, USA), $p$-nitrofenil butirat ( $p$-NPB) (Sigma, USA), asam galat (Sigma, China), kuersetin (Sima, India), folin ciocalteu (Merck, Jerman), DPPH (Aldrich, Jerman), buffer tris (Sigma, USA).

\section{Penyiapan Sampel}

Daun G. ulmifolia dikumpulkan dari Taman Nasional Meru Betiri, Jember, dan diidentifikasi di Kebun Raya Purwodadi, Jawa Timur. Daun disortir, dicuci, dan dikeringkan sebelum dihaluskan menjadi bubuk. Ekstraksi daun G. ulmifolia dilakukan dengan 3 (tiga) metode, yaitu ekstraksi dengan etanol, perebusan, dan infusa.

Ekstrak etanol dibuat dengan cara serbuk daun $G$. ulmifolia $200 \mathrm{~g}$ dimaserasi dengan $1 \mathrm{~L}$ etanol 70\% selama 24 jam, sambil sesekali diaduk. Setelah penyaringan, residu dimaserasi lagi dua kali dengan cara yang sama. Filtrat digabungkan dan dipekatkan dengan rotary evaporator
(Heidolph Laborota 4000) pada suhu dan tekanan rendah. Ekstrak pekat yang dihasilkan digunakan untuk pengujian lebih lanjut.

Rebusan dibuat berdasarkan metode tradisional, yakni penyiapan jamu [1]. Secara singkat, serbuk simplisia yang setara dengan 20 lembar daun direbus dengan 3 gelas air suling $( \pm 600 \mathrm{~mL}$ ) sampai volumenya tinggal $3 / 4$ volume semula. Selanjutnya dikeringkan dengan freeze dryer (Zirbus Vaco 5). Rebusan kering digunakan untuk pengujian lebih lanjut.

Infusa dibuat berdasarkan Farmakope Indonesia IV, yaitu $10 \mathrm{~g}$ serbuk simplisia diekstraksi dengan air suling pada suhu $90{ }^{\circ} \mathrm{C}$ selama 15 menit. Setelah dingin disaring dan dikeringkan dengan freeze dryer (Zirbus Vaco 5). Infusa kering ini digunakan untuk pengujian lebih lanjut.

Penentuan Kadar Fenol Total (Total Phenol Content $=$ TPC)

Kadar fenol total ekstrak ditentukan berdasarkan metode standar [15]. Secara singkat, $50 \mu \mathrm{L}$ ekstrak (1 mg/ $\mathrm{mL}$ ) atau standar asam galat (konsentrasi akhir 0,625; 1,25;

Tabel 1. Kadar fenol dan flavonoid total ekstrak etanol, rebusan, dan infusa daun G. ulmifolia

\begin{tabular}{lcc}
\hline \multicolumn{1}{c}{ Sampel } & Kadar Fenol Total (mg GAE/g) & Kadar Flavonoid Total (mg QE/g) \\
\hline Ekstrak etanol & $67,761 \pm 1,811^{\mathrm{a}}$ & $124,643 \pm 1,033^{\mathrm{a}}$ \\
rebusan & $31,220 \pm 0,159^{\mathrm{b}}$ & $39,584 \pm 8,026^{\mathrm{b}}$ \\
infusa & $38,400 \pm 2,348^{\mathrm{c}}$ & $35,943 \pm 8,469^{\mathrm{b}}$ \\
\hline
\end{tabular}

Huruf yang berbeda dalam satu kolom menunjukkan perbedaan yang signifikan $(\mathrm{P}<0.05)$ 


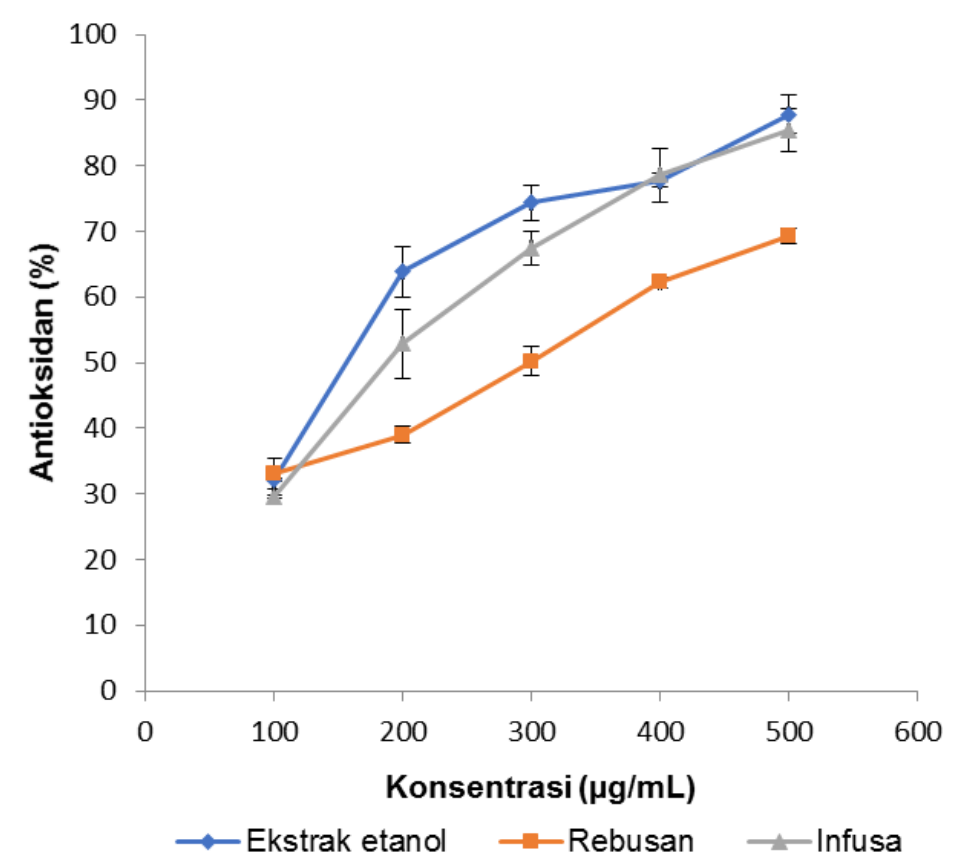

Gambar 3. Aktivitas antioksidan ekstrak etanol, rebusan, dan infusa daun G. ulmifolia

2,5; 3,75; dan $5 \mu \mathrm{g} / \mathrm{mL}$ ) dicampur dengan $1,25 \mathrm{~mL}$ reagen folin-ciocalteu (10\%) dan 1,25 $\mathrm{mL} \mathrm{Na}_{2} \mathrm{CO}_{3}(7 \%)$, kemudian diinkubasi selama 60 menit pada suhu kamar. Absorbansi campuran ini diukur menggunakan spektrofotometer UVVis (Hitachi U-1800) pada panjang gelombang $725 \mathrm{~nm}$. Kurva standar dibuat dengan memplot nilai absorbansi terhadap konsentrasi asam galat. Estimasi TPC dalam ekstrak ditentukan menggunakan persamaan kurva standar. Penentuan TPC dilakukan dalam tiga replikasi dan hasilnya dinyatakan dalam mg GAE/g ekstrak.

Penentuan Kadar Flavonoid Total (Total Flavonoids Content $=\mathrm{TFC}$ )

Kadar flavonoid total ditentukan berdasarkan metode kolorimetri yang mengacu pada metode yang sudah ada [16]. Larutan ekstrak $150 \mu \mathrm{L}(1 \mathrm{mg} / \mathrm{mL})$ atau standar kuersetin (konsentrasi akhir 5, 10, 20, 40, $60 \mu \mathrm{g}$ / $\mathrm{mL})$ ditambahkan ke dalam $400 \mu \mathrm{L}$ air suling. Kemudian ditambahkan dengan $30 \mu \mathrm{L} \mathrm{NaNO}_{2}(5 \%)$ dan $30 \mu \mathrm{L}$ $\mathrm{AlCl}_{3}$ (10\%). Setelah 6 menit, ditambahkan $200 \mu \mathrm{L} 1$ $\mathrm{M} \mathrm{NaOH}$ dan $240 \mu \mathrm{L}$ air suling. Campuran dibiarkan selama 15 menit, dan absorbansi diukur menggunakan spektrofotometer UV-Vis (Hitachi U-1800) pada panjang gelombang $415 \mathrm{~nm}$. Kurva standar dibuat dengan memplot nilai absorbansi terhadap konsentrasi kuersetin. Estimasi TFC ekstrak ditentukan dengan menggunakan persamaan kurva standar dan hasilnya dinyatakan dalam mg QE/g ekstrak. Penentuan TFC ini dilakukan dalam tiga replikasi.

\section{Uji Antioksidan}

Penentuan aktivitas antioksidan dari ekstrak daun G. ulmifolia terhadap 1,1-difenil-2-pikrillhidrazil (DPPH) mengacu pada metode Molyneux [17]. Larutan ekstrak 500 $\mu \mathrm{L}(2,5 ; 5 ; 7,5 ; 10 ;$ dan $12,5 \mu \mathrm{g} / \mathrm{mL})$ ditambahkan ke 500 $\mu \mathrm{L}$ larutan DPPH dalam metanol $(50 \mu \mathrm{g} / \mathrm{mL})$. Kemudian campuran diinkubasi di ruang gelap pada suhu ruang. Setelah 15 menit, nilai absorbansi diukur menggunakan spektrofotometer UV-Vis (Hitachi U-1800, Jepang) pada panjang gelombang $517 \mathrm{~nm}$. Pengujian dilakukan dalam tiga replikasi. Absorbansi (A) diubah menjadi persentase aktivitas antioksidan menggunakan persamaan berikut.

$$
\text { Aktivitas antioksidan }(\%)=\frac{\text { A blanko }- \text { A sampel }}{\text { A blanko }} \times 100 \%
$$

Regresi linier dibuat dengan memplot nilai aktivitas antioksidan terhadap konsentrasi ekstrak. Regresi linier ini digunakan untuk menghitung nilai $\mathrm{IC}_{50}$ dari ekstrak.

\section{Uji Antilipase}

Aktivitas antilipase ekstrak ditentukan dengan uji kolorimetri, di mana pelepasan $p$-nitrofenol dari $p$-nitrofenil butirat diukur berdasarkan metode yang telah dijelaskan sebelumnya [18]. Larutan lipase pankreas disiapkan segera sebelum digunakan. Lipase pankreas disuspensikan dalam buffer Tris- $\mathrm{HCl}$ (2,5 mM, pH 7,4 mengandung 2,5 mM $\mathrm{NaCl}$ ) menghasilkan konsentrasi $5 \mathrm{mg} / \mathrm{mL}$ (200 unit/mL) dan dicampur menggunakan pengaduk selama satu menit. 
Tabel 2. Nilai $\mathrm{IC}_{50}$ ekstrak etanol, rebusan, dan infusa daun G. ulmifolia

\begin{tabular}{lcc}
\hline \multirow{2}{*}{ Sampel } & \multicolumn{2}{c}{ IC $_{50}(\boldsymbol{\mu g} / \mathrm{mL})$} \\
\cline { 2 - 3 } & Antioksidan & Antilipase \\
\hline Ekstrak etanol & $6,544 \pm 0,271^{\mathrm{a}}$ & $307,280 \pm 21,430^{\mathrm{a}}$ \\
Rebusan & $10,121 \pm 0,468^{\mathrm{b}}$ & $465,832 \pm 72,184^{\mathrm{b}}$ \\
Infusa & $7,097 \pm 0,26^{\mathrm{a}}$ & $499,046 \pm 62,475^{\mathrm{b}}$ \\
\hline
\end{tabular}

Nilai dengan superskrip yang berbeda dalam satu kolom menunjukkan perbedaan yang signifikan $(\mathrm{p}<0.05)$

Suspensi kemudian disentrifugasi pada $6000 \mathrm{rpm}$ selama 10 menit, sehingga diperoleh supernatan yang yang berupa larutan jernih. $25 \mu \mathrm{L}$ larutan lipase pankreas dipreinkubasi dengan $20 \mu \mathrm{L}$ ekstrak (konsentrasi akhir 10, 20, 50, 200, 500 $\mu \mathrm{g} / \mathrm{mL}$ ) selama 15 menit pada suhu $37{ }^{\circ} \mathrm{C}$ dalam 96-well microplate. Kemudian ditambahkan $20 \mu \mathrm{L}$ substrat $p$-NPB (10 $\mathrm{mM}$ dalam asetonitril). Volume diencerkan sampai 200 $\mu \mathrm{L}$ menggunakan buffer Tris- $\mathrm{HCl}$ dan diinkubasi selama 5 menit sebelum absorbansi diukur menggunakan microplate reader (Dialab ELx800) pada $410 \mathrm{~nm}$. Pengujian dilakukan dalam tiga replikasi. Persentase penghambatan lipase dapat dihitung dengan persamaan berikut.

$$
\text { Hambatan lipase }(\%)=\frac{\text { A blanko }- \text { A sampel }}{\text { A blanko }} \times 100 \%
$$

Analisis statistik

Hasil dinyatakan sebagai rata-rata \pm standar deviasi (SD) dari tiga replikasi. Analisis regresi digunakan untuk menghitung TPC, TFC, dan $\mathrm{IC}_{50}$, sedangkan adanya perbedaan bermakna antara ekstrak etanol, rebusan, dan infusa ditentukan menggunakan analisis one-way ANOVA dilanjutkan LSD dengan nilai signifikansi 95\%.

\section{Hasil dan Diskusi}

Hasil rendemen ekstrak daun G. ulmifolia dirangkum dalam Gambar 2. Efisiensi ekstraksi ditentukan oleh hasil ekstraksi. Hasil ekstraksi daun G. ulmifolia menunjukkan bahwa hasil tertinggi diperoleh dari rebusan $(10,50 \%)$ diikuti oleh infus $(9,44 \%)$ dan ekstraksi etanol (6,13\%).

Kadar fenol total dari ekstrak dihitung dari kurva standar asam galat menggunakan persamaan korelasi $\mathrm{y}$ $=0,1847 \mathrm{x}+0,0106$ dengan koefisien determinasi $\mathrm{R}^{2}=$ 0,9875. Sedangkan kadar flavonoid total dihitung dari kurva standar kuersetin menggunakan persamaan korelasi $\mathrm{y}=0,0141 \mathrm{x}+0,0926$ dengan koefisien determinasi $\mathrm{R}^{2}$ $=0,9972$. Kadar fenol dan flavonoid total untuk ekstrak etanol, rebusan, dan infusa dirangkum dalam Tabel 1. Ekstrak etanol mengandung fenol total tertinggi, diikuti oleh infusa dan rebusan. Demikian pula, ekstrak etanol memiliki kadar flavonoid total tertinggi. Tetapi kadar flavonoid total rebusan dan infusa tidak menunjukkan perbedaan yang signifikan.

Hasil ekstrak dan jumlah senyawa bioaktif yang
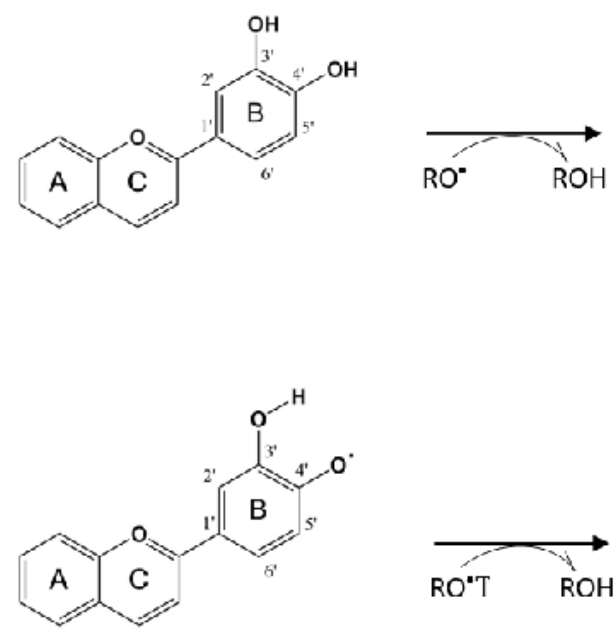

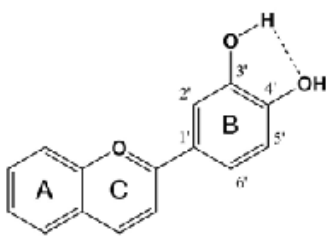

Radikal flavonoid yang distabilkan dengan ikatan hidrogen

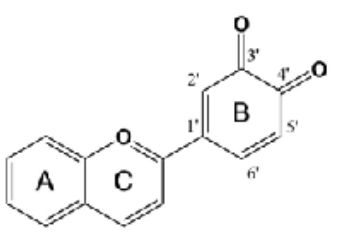

Struktur kuinon yang stabil

Gambar 4. Mekanisme antioksidan flavonoid (3',4'-diOH flavonoid) $\mathrm{RO} \bullet=$ radikal, $\mathrm{ROH}=$ radikal terstabilkan 

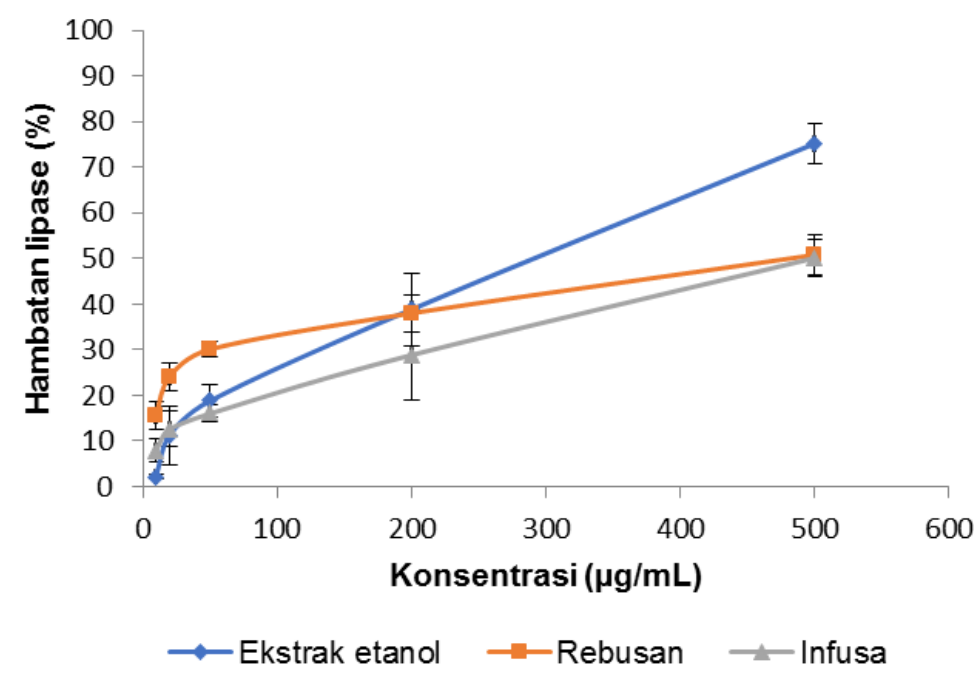

Gambar 5. Aktivitas antilipase ekstrak etanol, rebusan, dan infusa daun G. ulmifolia

terekstraksi dari bahan tanaman tergantung pada beberapa faktor, diantaranya metode dan pelarut untuk ekstraksi. Demikian juga aktivitas biologis ekstrak tergantung pada teknik ekstraksi [19]. Hasil ekstrak tertinggi ditunjukkan oleh rebusan. Hasil ini konsisten dengan laporan sebelumnya yang menunjukkan bahwa hasil ekstraksi dengan air lebih tinggi dibandingkan dengan etanol [20]. Selain metabolit sekunder, daun G. ulmifolia juga mengandung metabolit primer yaitu protein dan karbohidrat (gum xanthan) [21,22], yang diproduksi dalam jumlah banyak dibandingkan metabolit sekunder. Kedua metabolit primer ini bersifat polar, sehingga lebih mudah larut ke dalam air [23]. Kemungkinan hal ini yang menyebabkan rendemen rebusan dan infusa lebih banyak dibandingkan ekstrak etanol [24]. Sebaliknya, kandungan fenolik total dan flavonoid total ekstrak etanol lebih tinggi daripada rebusan dan infusa. Senyawa-senyawa fenolik dan aglikon flavonoid bersifat semipolar yang larut dalam etanol [23], sehingga meskipun rendemen ekstrak etanol paling rendah, tetapi memiliki kandungan fenol dan flavonoid total tertinggi. Hasil rendemen rebusan lebih tinggi daripada infusa. Seperti disebutkan di atas, rebusan dibuat dengan memanaskan $100{ }^{\circ} \mathrm{C}$ (air mendidih), sedangkan infus dibuat dengan memanaskan $90{ }^{\circ} \mathrm{C}$ (dalam penangas air). Hasil ini membuktikan bahwa suhu mempengaruhi hasil ekstraksi, peningkatan suhu dapat meningkatkan hasil ekstraksi karena terjadinya peningkatan kelarutan senyawa metabolit skunder dalam simplisia tanaman $[25,26]$.

Hasil uji aktivitas antioksidan menunjukkan bahwa ekstrak etanol, rebusan, dan infusa memiliki aktivitas antioksidan yang tergantung konsentrasi seperti yang diperlihatkan pada Gambar 3. Ekstrak etanol memiliki aktivitas antioksidan tertinggi, diikuti oleh infusa dan rebusan. Hal ini ditunjukkan oleh nilai $\mathrm{IC}_{50}$, dimana nilai $\mathrm{IC}_{50}$ terendah dimiliki oleh ekstrak etanol (Tabel 2). Aktivitas antioksidan mungkin terkait dengan kandungan fenolik dan flavonoid [27]. Faktanya, ekstrak ini memiliki kadar fenol dan flavonoid total tertinggi. Fenol adalah senyawa yang memiliki setidaknya satu gugus hidroksil dan keberadaan gugus hidroksil ini menyebabkan semua senyawa fenolik menjadi reduktan. Reduksi berarti transfer elektron, di mana elektron ini disediakan oleh fenol sebagai atom hidrogen dengan elektron tunggal $(\mathrm{H} \bullet)$. Atom ini dihasilkan dari pemecahan ikatan $\mathrm{O}-\mathrm{H}$ dengan proses di mana masing-masing fragmen mempertahankan salah satu elektron. $\mathrm{H}$ • ini akan mengurangi jumlah oksidasi yang disebabkan oleh radikal bebas [28,29]. Flavonoid dapat berkontribusi pada aktivitas antioksidan dari ekstrak tanaman, bahkan pada konsentrasi rendah. Hal ini terutama disebabkan oleh adanya ikatan rangkap terkonjugasi, gugus hidroksil pada C4' dan C3', dan katekol dalam cincin B dalam struktur flavonoid (Gambar 4). Struktur semacam itu menjadikan flavonoid sebagai sasaran untuk diserang oleh radikal bebas dengan cara menggerakkan awan elektron di sekitar cincin aromatik dan donor elektron, sehingga menghambat reaksi berantai dan menstabilkan bentuk radikal $[26,30]$.

Hasil uji aktivitas antilipase menunjukkan bahwa persentase penghambatan enzim meningkat dalam tren hiperbolik seiring dengan peningkatan konsentrasi ekstrak (Gambar 5). Sama seperti aktivitas antioksidan, ekstrak etanol juga menunjukkan aktivitas antilipase tertinggi. Namun, aktivitas antilipase rebusan dan infusa tidak menunjukkan perbedaan yang signifikan (Tabel 
2). Senyawa yang mungkin berkontribusi pada aktivitas adalah fenol dan flavonoid. Senyawa fenol, seperti tanin, dapat membentuk senyawa kompleks yang larut maupun tidak larut dengan enzim karena pengikatan non-spesifik pada permukaan enzim [31]. Demikian juga flavonoid dapat bertindak sebagai inhibitor enzim karena mereka membentuk senyawa kompleks dengan logam seperti tembaga, magnesium, dan seng yang diperlukan untuk pemeliharaan konformasi tiga dimensi enzim [32]. Namun, efek penghambatan flavonoid pada enzim lipase lebih dominan daripada senyawa fenol lainnya [33].

Patogenesis obesitas merupakan proses kompleks yang dipicu oleh konsumsi lemak yang berlebihan dan kondisi hipoksia dalam jaringan adiposa. Kombinasi kedua kondisi ini memicu adiposit untuk menghasilkan ROS dan selanjutnya menyebabkan kondisi yang dikenal sebagai stres oksidatif. Kondisi ini merangsang diferensiasi adiposit dan akumulasi lemak dalam jaringan adiposa [34]. Aktivitas antilipase dapat mengurangi penyerapan lemak yang berlebihan, sementara antioksidan mencegah stres oksidatif. Oleh sebab itu aktivitas antioksidan dan antilipase dapat secara sinergis mencegah obesitas.

Hasil penelitian ini memberikan justifikasi penggunaan daun G. ulmifolia dalam pengobatan tradisional untuk pengelolaan obesitas. Oleh karena itu daun ini dapat digunakan sebagai alternatif atau strategi pelengkap dalam mengelola komorbiditas terkait obesitas dan juga sebagai bahan baku untuk pengembangan obat antiobesitas di masa depan. Hasil ini juga mengungkapkan untuk pertama kalinya bahwa ekstraksi dengan etanol dapat menghasilkan kandungan fenol dan flavonoid total yang lebih tinggi dan memberikan efek antioksidan dan antilipase yang lebih baik dibandingkan ekstraksi dengan air seperti pada penggunaan tradisional.

\section{Kesimpulan}

Hasil ekstraksi daun G. ulmifolia dengan etanol memberikan rendemen yang terendah dibandingkan dengan metode ekstraksi lainnya. Namun, ekstrak etanol memiliki kadar fenol dan flavonoid total serta aktivitas antioksidan dan antilipase tertinggi dibandingkan dengan rebusan dan infusa.

\section{Ucapan Terima Kasih}

Terimakasih kepada Universitas Jember yang telah mendanai penelitian ini melalui Hibah KeRis tahun 2019 dengan nomor kontrak 1442/UN25.3.1/LT/2019.

\section{Referensi}

[1] Mardisiswojo S, Rajakmangunsudarso H. Cabe Puyang Warisan Nenek Moyang. Jakarta: Balai Pustaka, 1985.

[2] Sukandar EY, Elfahmi, Nurdewi. Pengaruh pemberian ekstrak air daun jati belanda (Guazuma Ulmifolia Lamk.) terhadap kadar lipid darah pada tikus jantan. JKM. 2009;8(2):102-14.

[3] Sukandar EY, Nurdewi, Elfahmi. Antihypercholesteromic effect of combination of Guazuma ulmfolia Lamk. leaves and Curcuma xanthorriza Roxb. Rhizomes extract in Wistar rats. Int J Pharmacol. 2012;8(4):277-82. https://doi.org/10.3923/ijp.2012.277.282

[4] Sumaiyah, Triandini R, Dalimunthe A. The effects of the adduction of effervescent powder of bastrad cedar leaf (Guazuma Ulmifolia Lamk.) extract toward weight reduction of male mice. Asian J Pharm Clin Res. 2018;11(1):190-3. https://doi.org/10.22159/ajpcr.2018. v11s1.26604

[5] Alias N, Leow TC, Ali MS, Tajudin AA, Salleh AB, Abd Rahman RNZ. Anti-obesity potential of selected tropical plants via pancreatic lipase inhibition. Adv Obesity, Weight Manag Control. 2017; 6(4):122-31. https://doi.org/10.15406/aowmc.2017.06.00163

[6] Dechakhamphu A, Wongchum N. Screening for anti-pancreatic lipase properties of 28 traditional Thai medicinal herbs. Asian Pac J Trop Biomed. 2015;5(12):1042-5. https://doi.org/10.1016/j. apjtb.2015.09.012

[7] Patil JU, Biradar SD. Pharmacognostic Study of Guazuma ulmifolia. Int Res J Pharm. 2013;4(4):130-131. https://doi.org/107897/2230$\underline{8407.04425}$

[8] Junior JT, de Morais SM, Gomez CV, Molas CC, Rolon M, Boligon AA et al. Phenolic composition and antiparasitic activity of plants from the Brazilian Northeast "Cerrado". Saudi J Biol Sci. 2016;23(3): 43440. https://doi.org/10.1016/j.sjbs.2015.10.009

[9] Anonim. Farmakope Herbal Indonesia Edisi I. Jakarta: Departemen Kesehatan Republik Indonesia; 2008.

[10] Iswantini D, Silitonga RF, Martatilofa E, Darusman LK. Zingiber cassumunar, Guazuma ulmifolia, and Murraya paniculata extracts as antiobesity: in vitro inhibitory effect on pancreatic lipase activity. HAYATI J Biosci. 2011;18(1):6-10. https://doi.org/10.4308/ hjb.18.1.6

[11] Liu S, Li D, Huang B, Chen Y, Lu X, Wang Y. Inhibition of pancreatic lipase, $\alpha$-glucosidase, $\alpha$-amylase, and hypolipidemic effects of the total flavonoids from Nelumbo nucifera leaves. J Ethnopharmacol. 2013;149(1):263-9. https://doi.org/10.1016/i.jep.2013.06.034

[12] Ado MA, Abas F, Mohammed AS, Ghazali HM. Anti- and prolipase activity of selected medicinal, herbal and aquatic plants, and structure elucidation of an anti-lipase compound. Molecules. 2013;18(12):14651-69. https://doi.org/10.3390/ molecules181214651

[13] Rice-Evans CA, Miller NJ, Paganga G. Structure-antioxidant activity relationships of flavonoids and phenolic acids. Free Radic Biol Med. 1996;20(7):933-56. https://doi.org/10.1016/08915849(95)02227-9

[14] Stalikas CD. Extraction, separation, and detection methods for phenolic acids and flavonoids. J Sep Sci. 2007;30(18):3268-95. https://doi.org/10.1002/issc.200700261

[15] Ajayi TO, Moody JO, Abiose IM, Ezeoku NJ. Comparative total phenolic content, anti-lipase and antioxidant activities of two Nigerian Aframomum species. Niger J Nat Prod Med. 2017;20:12-9. https://doi.org/10.4314/njnpm.v20i1.3

[16] Baba SA, Malik SA. Determination of total phenolic and flavonoid content, antimicrobial and antioxidant activity of a root extract of Arisaema jacquemontii Blume. J Taibah Univ Sci. 2015;9(4):449-54. https://doi.org/10.1016/j.jtusci.2014.11.001

[17] Molyneux P. The use of the stable free radical diphenylpicryl-hydrazyl (DPPH) for estimating anti-oxidant activity. Songklanakarin J Sci Technol 2004;26(2):211-9.

[18] Bustanji Y, Mohammad M, Hudaib M, Tawaha K, Al-Masri IM, AlKhatib HS, et al. Screening of some medicinal plants for their pancreatic lipase inhibitory potential. Jordan J Pharm Sci. 2011;4(2): $81-8$ 
[19] Dhanani T, Shah S, Gajbhiye NA, Kumar S. Effect of extraction methods on yield, phytochemical constituents and antioxidant activity of Withania somnifera. Arab J Chem. 2017;10:S1193-9. https://doi.org/10.1016/j.arabjc.2013.02.015

[20] Truong DH, Nguyen DH, Ta NTA, Bui AVD, Do TH, Nguyen HC. Evaluation of the use of different solvents for phytochemical constituents, antioxidants, and in vitro anti-inflammatory activities of Severinia buxifolia. J Food Qual. 2019:8178294. https://doi. org/10.1155/2019/8178294

[21] Kumar NS, Gurunani SG. Guazuma ulmifolia Lam: a review for future view. J Med Plants Stud. 2019;7(2):205-10.

[22] Sharma M, Prasad SB. Standardisation of Guazuma tomentosa leaf. Int J Pharmacogn Phytochem Res. 2014;6(4):1010-4.

[23] Widyawati SP, Budianta TDW, Kusuma FA, Wijaya EL. Difference of solvent polarity to phytochemical content and antioxidant activity of Pluchea indicia Less leaves extracts. Int J Pharmacogn Phytochem Res. 2014;6(4):850-5.

[24] Do QD, Angkawijaya AE, Tran-Nguyen PL, Huynh LH, Soetaredjo FE, Ismadji S, et al. Effect of extraction solvent on total phenol content, total flavonoid content, and antioxidant activity of Limnophila aromatica. J Food Drug Anal. 2014; 22(3):296-302. https://doi. org/10.1016/j.jfda.2013.11.001

[25] Sulaiman ISC, Basri M, Masoumi HRF, Chee WJ, Ashari SE, Ismail M. Effects of temperature, time, and solvent ratio on the extraction of phenolic compounds and the anti-radical activity of Clinacanthus nutans Lindau leaves by response surface methodology. Chem Cent J. 2017;11:54. https://doi.org/10.1186/s13065-017-0285-1

[26] de Oliveira GRB, Simao AA, Pereira LLS, Rocha FD, Raposo NRB, de Oliveira VR, et al. Stem bark extracts of Endopleura uchi (Huber) Cuatrec: Inhibition of pancreatic lipase and antioxidant activity. J Med Plants Res. 2017;11(30):472-79. https://doi.org/10.5897/ JMPR2016.6271
[27] Simamora A, Paramita L, Hamid NABM, Santoso AW, Timotius KH. In vitro antidiabetic and antioxidant activities of aqueous extract from the leaf and fruit of Psidium guajava L. Indones Biomed J. 2018;10(2):156-64. https://doi.org/10.18585/inabj.v10i2.402

[28] Laguerre M, Lecomte J, Villeneuve P. The physico-chemical basis of phenolic antioxidant activity. Lipid Technol. 2014;26(3):59-62. https://doi.org/10.1002/lite.201400017

[29] Rusmana D, Wahyudianingsih R, Elisabeth M, Balqis, Maesaroh, Widowati W. Antioxidant activity of Phyllanthus niruri extract, rutin and quercetin. Indones Biomed J. 2017;9(2):84-90. https://doi. org/10.18585/inabj.v9i2.281

[30] Katz DL, Doughty K, Ali A. Cocoa and chocolate in human health and disease. Antioxidants Redox Signal. 2011;15(10):2779-811. https:// doi.org/10.1089/ars.2010.3697

[31] Buchholz T, Melzig MF. Polyphenolic Compounds as pancreatic lipase inhibitors. Planta Med. 2015;81(10):771-83. https://doi. org/10.1055/s-0035-1546173

[32] Dzomba P, Musekiwa C. Anti-obesity and antioxidant activity of dietary flavonoids from Dioscorea steriscus tubers. J Coast Life Med. 2014;2(6):465-70. https://doi.org/10.12980/JCLM.2.201414B8

[33] Martinez-Gonzalez Al, Díaz-Sánchez ÁG, De La Rosa LA, VargasRequena CL, Bustos-Jaimes I, Alvarez-Parrilla E. Polyphenolic compounds and digestive enzymes: In vitro non-covalent interactions. Molecules. 2017;22(669):1-24. https://dx.doi. org/10.3390/molecules22040669

[34] Utami S, Endrini S, Nafik S, Lestari IMT, Anindya D, Bakar EA, et al. In vitro antioxidant and anti-obesity activities of freeze-dried Canarium sp., Averrhoa bilimbi L. and Malus domestica. Indones Biomed J 2019;11(3):320-6. https://doi.org/10.18585/inabj.v11i3.728. 